\title{
The Importance, Content and Teaching of the Political Geography Course in Social Studies Undergraduate Programs
}

\author{
Tulay Ocal \\ Correspondence: Tulay Ocal, Social Studies Education, Faculty of Education, Nigde University, Nigde, Turkey.
}

Received: May 6, 2016

doi:10.11114/jets.v4i6.1594

Accepted: May 13, 2016

Online Published: May 21, 2016

URL: http://dx.doi.org/10.11114/jets.v4i6.1594

\begin{abstract}
Today, big countries and other countries inside their axes have entered power wars in regions where underground and aboveground sources are important. One of the characteristics of countries where these power wars take place is them not being able to understand the current world politics and elements of political geography. These countries cannot develop modern strategies for current political needs. Like these countries, Turkey has not yet understood the importance of political geography and could not produce an effective work on today's world politics. We cannot use our regional power in line with our interests due to policies without a specific objective and system and changeable with each government. To use and direct our regional power, tremendous responsibility falls on the shoulders of social studies teachers. Bequeathing the importance of our geopolitical location to young generations is one of the most important responsibilities of social studies teacher candidates. In addition to not being current, the content of political geography course taught in social Studies undergraduate programs are repetition of old information. Therefore, political geography subjects in these programs should be organized according to today's word politics and more emphasis should be given to the importance of our current geopolitical location. Having an important geopolitical location and being a great power in the Middle East, in a country like Turkey, people should be more aware in this subject.
\end{abstract}

Keywords: Turkish political geography, social studies education, political geography course content

\section{Introduction}

Today, big countries and other countries inside their axes entered power wars in some regions where underground and aboveground resources are important. In today's world, with these developments political geography protected its definition but went through a great change in terms of content. To understand these changes, one should examine the definition of political geography. There are many approaches towards defining political geography. For some geographers, political geography is related to studies on political regional units, borders and administrative sub-units (Alexander, 1963, Goblet, 1955; Jones et al. 2004). First of all, political geography examines the geographical elements that play a role in distribution of political regions and in why these regions gain political importance or why they take a backseat and examines the mutual relations inside a specific space (Goney, 1979). In other words, political geography is a science that identifies specific opinions and understandings related to the art of organizing and executing state affairs by examining distribution of natural, human and economic events and their reasons and results in the world, in a region or in a country (Ozey, 2013).

It should be noted that the subject of political geography is to study the relationship between a country and the place that country is founded on (Akengin, 2010). Political geography is a vital science that provides strategy development towards future based on the locations the countries hold on earth. A geographer should always bear in mind that geography is strategic information and strategic information is dangerous (Ozey, 2013). When the scientific publication catalogs of countries like the US, Russia, England, Germany, France, China and Japan where the importance of this strategic information in political geography is understood are examined, the increase and abundance of publications regarding this issue is clearly evident (Ozey, 2013). This helps us better understand these countries' source of power that provides the foundations of their rule. Just like the Middle Eastern countries, the backward countries which lag behind or could not make remarkable studies in this field witness disorder and conflicts. In addition to being inadequate in fields covering political geography subjects, these countries cannot develop contemporary strategies towards current political needs.

Turkey followed a different development process than the Middle East. The importance of Turkey's location at the 
continental level is well known. Turkey is one of the three countries that has land on two continents. These three countries are Russia, Turkey and Egypt. Turkey has land on two continents. Also, Turkey is at the junction of three continents. Geopolitically, Turkey is the hinge of the World Island, i.e. the central land between Asia, Europe and Africa. Turkey is both the lock and key of this hinge (Ilhan, 1989). In this respect, Ramsay presented this fact in the best way by writing this about the Anatolian Peninsula: "Since the beginning of history, the Anatolian Peninsula became the war zone of East and West; the religion, art and civilization of the East passed to Greece from this bridge; the later developed Greek Civilization used this bridge to return back to conquer and captivate the East through Alexander the Great and to change Asia to the heart of India" (Ramsay, 1963). This geography where the East and West continuously came face to face provoked the greed of its distant and near neighbors and became an area where political conflicts with various interests continued. The countries and civilizations founded here got stronger with the features specific to the Anatolian geography but at the same time they invited negative factors that wore out and shook their existing powers. When the events that swept the Ottoman Empire and later the Turkish republic especially since the 18th century are examined, it is evident how much Turkey's geographical location positively and negatively affected its history (Gunel, 2004).

As for today, with the opportunities given by its geographical location and today's geopolitical conditions, Turkey is one of the countries that has the most political options at the global and regional level. In addition to Turkey's physical characteristics, its unique human characteristics are also the reason why it is the country with the most political options (Ilhan, 2000; http://www.tasam.org). With all its characteristics, Turkey is a border country and has to take measures appropriate to this characteristic's concerns. Every country with a place, purpose and value at the world geography level and every country that is affected by problems at this level will consider dominating Turkey. Since Turkey has an important place in all the problems the countries face in the region, these countries will attempt to influence Turkey. Their attempts to influence Turkey cause threats. Our important geographical power also stores every kind of threat and raises our sensitivity (Ilhan, 1989). Knowing our country's geographical characteristics and its geopolitical position in-depth is effective in raising this sensitivity. Geography and its sub-branch, political geography, are the only sciences that ensure our specialization in these subjects and provides information. For this reason, in Turkey, it is important to know the developmental process of Geography and Political Geography and the developmental phases of teaching these subjects.

As an independent unit, academic geography in Turkey has been continuing its existence under the German (the first foreign faculty member was a German named Erich Obst who worked between 1915-1920 in Istanbul) and French influences with literary and geographical inspirations since 1915 and especially since the Geography Department was founded in Istanbul University. In 1909, Faik Sabri (Duran), an extraordinary man, was sent first to Loius Le-Grand to follow Monsieur Fallex's classes and later sent to Sorbonne to follow L. Gallois and Monsieur Fallex's classes. Similarly, examining the first articles published in the Journal of Darulfunun Faculty of Arts (Darulfunun Edebiyat Fakultesi Dergisi) will help to review the historical order and the common assessments again. Published between the years 1916-1933, this striking journal included articles on geography starting from its second issue. The journal surprisingly gave weight to geographical studies between the years 1927-1932 and comprehensive translations of A. Demangeon were made. In addition to Demangeon, during these first years when geography was being structured R. Blanchard (1925) was another important person who was mentioned and cited frequently. Furthermore, a study on Théodore Lefebvre who at the end of 1925 came to give lectures at Istanbul University, not to Galatasaray High School like the Annales de Géographie Journal claimed in 1947 would have been beneficial. The articles Lefebvre sent to Annales de Géographie journal on contemporary Turkey are still cited. In addition to all of these, understanding the important role the German geographers played points to the necessity of examining this role in-depth. These German geographers taught at Ankara University's Department of Geography during the Second Word War and Hebert Louis was the one who stood out. With all names mentioned above, holding the Turkish Geography Conference for the first time in 1941 and starting to publish the Turkish Geography Journal in 1943 have a place in the institutionalization of republican geography in the capital, Ankara. Only a draft of an unfinished research project, after this short historical reminder, the question of why this imperative change took place can be asked. According to our point of view, the problem arises from the difficulty of emergence and acceptance of geographical studies in Turkey, the inner structure of the discipline and the weak position the department holds in universities. First, it should be remembered that when compared with France, the resources allocated to research are being reduced, our colleagues working in state universities work with low salaries and can only do research after long working hours. Furthermore, as in many other countries, in Turkey geography is a discipline where geography teachers are trained for high schools. Out of the 29 aforementioned geography departments, 10 of them are clearly for teacher training (department of Geography Education) (Yavan \& Acar, 2012).

The developmental phase of Political Geography in Geography started after the developments in the world. The first 
book on political geography published is Suha Goney's Political Geography that was published in 1979. In this book, the historical developments about the political geography concept were discussed but also the effects of physical geography on the formation of political geography were explained in detail. In Kamil Gunel's book, Political Power of Geography, static factors, area, shape, borders and locations were analyzed by using examples from different countries. Also, the political geography characteristics arising from Turkey's location were presented. In Ramazan Ozey's Political Geography, current examples were given by producing outstanding policies from physical, human and economic characteristics shaping political geography and the importance of political geography in world politics were discussed. Also, for a powerful future the book is an important strategic reference for Turkish people because of the Turkish Dominance Theory developed by the writer and the geopolitical theories analyzed. In addition, there is satisfying information on international organizations. Ramazan Ozay has many other works on political geography. In recent years, I. Yasar Hacisalihoglu, Servet Karabag, Hamza Akengin and Hayati Doganay published works on political geography (Arıbas, 2007). In recent years, also, Taskın Deniz has been working on Middle East and Turkey's political geography and Muazzez Harunogullari on energy resources and political geography.

In an information society, it is vital for individuals to learn subjects on political geography. Other than geography and social studies education departments, these subjects can be taught in many other departments under two courses: Geography of Countries and Political Geography (Aribas, 2007). Political Geography as a course is only taught in Faculties of Political Science and International relations. This causes political geography to only be limited with academic circles. Social Studies Education programs in faculties of education are bridges that pass information to the people. Thus, with this program political geography will not be limited to the academic circles but will spread to a wider audience. Teaching political geography is an important milestone in the construction of a conscious society. The courses taught at education faculties' social studies education departments, history and geography courses dominate the programs. When the concepts of social sciences, history and geography are examined, it is seen that they are all closely related. Social sciences, a wider concept including history and geography, aim to systematically examine people, the relationships between people, people and society, people and objects and aim to present information based on scientific methods (Demircioglu, 2005). Social studies is a study area that aims to prepare critical thinking and skillful democratic citizens equipped with fundamental democratic values in a global world and aims to study the interaction of people with their physical and social surroundings with an interdisciplinary approach using other sciences' content and methods (Doganay, 2004; Yesilbursa, 2008). The world is made up of various countries' sovereignty territories. The conflicts and wars in the world start from not being able share these sovereignty territories. Political geographers have known for a long time the dependency of countries on each other and their personal initiatives. In this kind of structure, the students must understand the roles they have in the world (Geography for Life, 1994; Davidson, et al. 1998). Social Studies teachers are the ones who will teach this. For this reason, giving the course content and teaching methods of political geography course in social studies education pragrams is of paramount importance.

The political geography subjects of the Geography course in social studies programs include Turkey's neighbors, its relations with its neighbors and the effect of neighboring countries and other powers have on Turkey. These make up the citizenship identity of people. In a person who learns his/her geography, citizenship awareness develops. People feel themselves responsible for the society they live in and fro the environment. In this respect, geography education cannot offer an effective education in our country because a person should know other cultures and countries to have his/her own identity, citizenship awareness and civic consciousness. Today, the geography education given cannot achieve this (Akinoglu, 2006). Included in the geography education, political geography education is of great importance in itself. The purposes of political geography education are to teach the importance of political geography in the past and today, to discuss the effects of political geography's role in world history on empires and countries, to teach the role of physical and human geography that are the subjects of political geography plays in world politics and to teach how great powers use geography and the struggles they have given to have a say in the world.

Today, especially with the new developments the world has become a global village and regional conflicts and wars have increased. These increase the importance teaching political geography subjects in today's world. The students, i.e. future generations, should learn the word political conjuncture and be informed about political geography subjects. Therefore, in this study, the content of the political geography course taught in education faculties' social studies education programs and how they are taught will be examined.

\subsection{Study Purpose and Importance}

The purpose of this study is to discuss the position of the political geography course taught in education faculties' social studies education programs. One of the purposes of the political geography course is to train teacher candidates who know their word and their country. In this globalized world, the distances got shortened. An event that happened on one side of the world affects even the other side of the world. A crisis in Africa can affect another country kilometers away. In a fast-changing world, a social studies teacher candidate should not lag behind the developments in the world and 
should have the capacity to understand and interpret these developments. In order to provide this, the subjects taught in political geography course should be regularly updated and should adapt to the changing world politics. One of the purposes of this study is to examine the currency of subjects taught in political geography. In addition to this, examination of modern teaching techniques and materials that can be used during the teaching of political geography course was another purpose of the study.

\subsection{Method}

Survey method, one of the qualitative research methods, was employed in this study. Obtained findings were subjected to descriptive analysis. Written materials regarding the problem and purpose were examined. These materials were examined, interpreted and inferences were made.

\subsection{Findings and Comments}

In Turkey, a supreme interuniversity board supervises the universities and determines the course contents of some faculties in universities. To achieve this, a commission made up of experts in their fields is formed. This commission determines and presents the course contents taught in departments. The supreme interuniversity board examines the suggestions, makes the necessary changes and determines the course contents to be taught in Turkish universities. The course content taught in departments of education faculties is also determined in this way.

The content of the political geography course taught in social studies education departments in Turkish universities' education faculties consists of the following:

1. Definitions, main opinions on political geography,

2. Physical factors in political geography, position, area, borders, landforms, climate, water, lands, natural resources,

3. Human factors in political geography, population, culture, military, political and economic communities,

4. Political alliances Turkey is a member of, NATO, the EU,

5. Middle Eastern countries

6. Balkan countries

7. Relations with the Caucasian countries

8. Turkic countries

9. Cross-border waters, straits, continental shelf and the Aegean problem,

\section{OECD countries}

11. Political and economic organizations in the world (http://www.nigde.edu.tr).The political geography course subjects taught in education faculties' social studies education programs do not include the political developments of the recent periods. However, Turkey is a bridge that connects the Mediterranean to the Black Sea and the Balkans, The Caucasus and the Middle East together. Cradle for many different civilizations for centuries, Turkey, a border country, is not only a region that synthesizes the cultures of the East and the West but also is at the center of the Turkish world. Kjellen and Haushofer stress the importance of a country producing enough for its own needs not to be dependent on other countries. Thus, while the country ensures its economic independence, it will also balance its structure. Turkey should not only ensure its national security in terms of military but also should ensure its cultural, social and educational security. It is possible to integrate the subjects Haushofer focusses on such as natural, physical and appropriate borders, cultural borders and appropriate military borders with the example of Turkey. According to Spykman's theory, a country should establish a collective security policy to protect its power balance. This is what Turkey needs to do. In his work titled "Chessboard", Z. Brzezinski divided countries into two: active geostrategic players and geopolitical pivots. He stated that the countries in Group 1 have national ambitions. Therefore, normally classified under Group 2, Turkey can also be classified under Group 1. Allocating fewer budget to education compared to West European countries, Turkey has become the topic of conversation due to the educational reforms it made in recent years. However, Turkey is still trying to establish the educational system and cope with a system that has many problems. Particularly there are problems regarding course programs and contents (http://www.tasam.org.tr). Moreover, in recent years, the political geography course does not include information like the Caucasus, Ukraine, North African countries and Arab countries. This information definitely concerns the world and our country. For example, The Middle East and the North Africa witness the domination struggle of the powerful countries because of their place on the transition routes of important waterways and the existence of rich energy resources like oil and natural gas for the last 150 years. Because of these, these regions do not lose their importance for political geography (Deniz, 2013). The political, military and socio-economic intervention to the Middle East especially in the last 100 years show the importance of the region in every aspect (Deniz, 2012) (Figure 1). The people's movement starting in Tunisia at the end of 2010 can be given as an example to this 
intervention. This people's movement ended with the government being overthrown. With a domino effect, these movements spread to Egypt and Libya respectively and the governments were overthrown. By the time 2011, the next stop of people's movements became Syria. The longest and the most violent people's movement occurred in Syria. Because of the regime's violent and fear policies, hundred thousands of people lost their lives and millions of people became refugees (Sen, 2013; https://www.academia.edu).

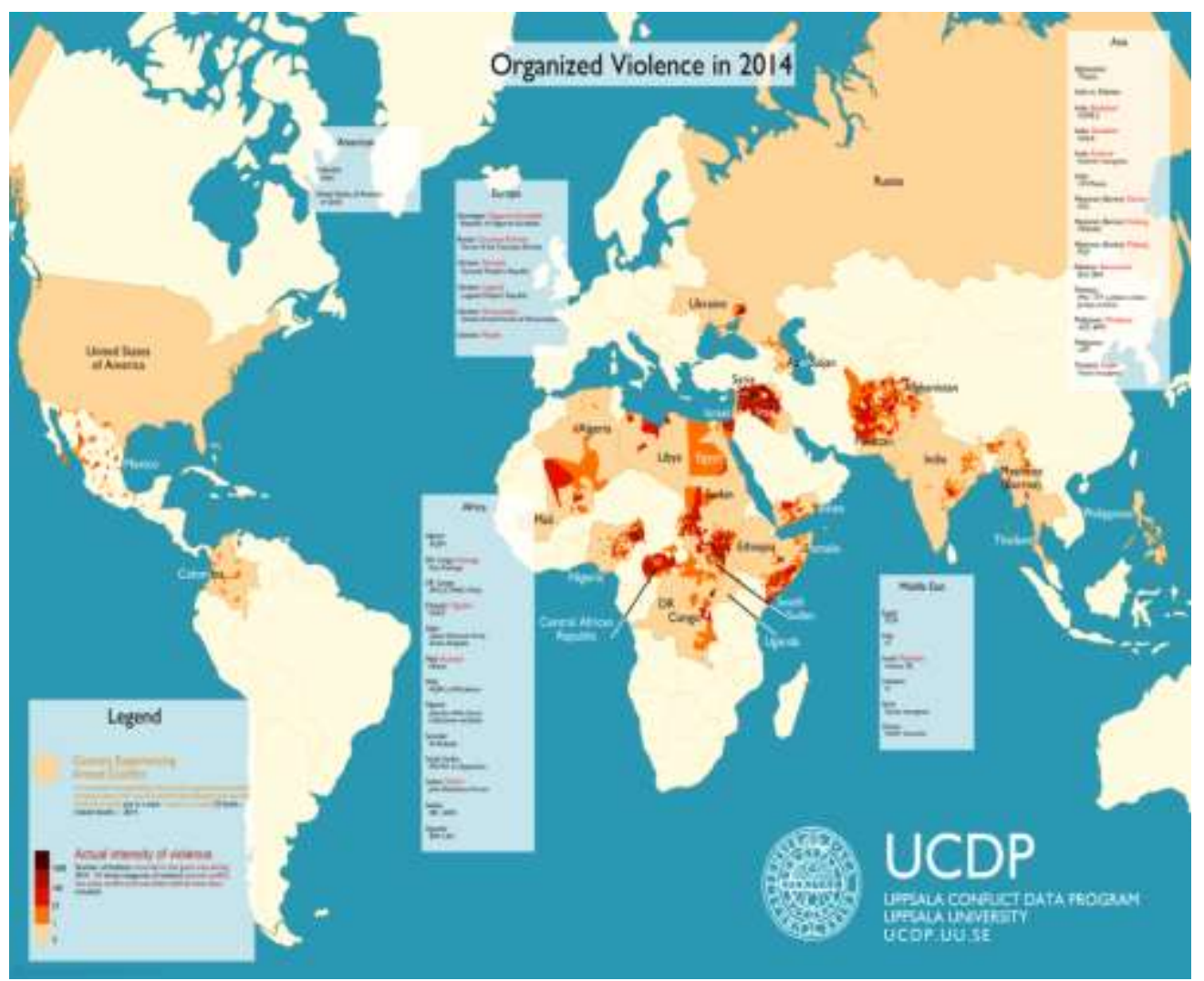

Figure 1. World's Conflict Regions, One of the Subjects of Political Geography (http://www.pcr.uu.se/digitalAssets/66/66314_1map14.png).

Like these problems, wars and treaties concerning the future of our country led us to pay many prices in the past. Treaty of Sevres at the end of the Ottoman period, Treaty of Lausanne concerning the Straits at the end of our War of Independence and Hatay becoming a Turkish province after a referendum can be considered as examples. Not to encounter the similar problems in the future, it is extremely important to include the developments happening in the word and the conflicts fought in the neighboring countries into the political geography courses. The social studies teacher candidates should be made aware and informed about these subjects. The religious and sectarian groups were taken into consideration while the Asian, African and Middle Eastern countries' borders were drawn after the First and Second World Wars and the same method is still being used today for new formations. This should be in the political geography course content in detail. While this same tactic is being used especially in underdeveloped and developing countries, these increase day by day. The political geography course should emphasize the effort the powerful countries make to split and separate the countries with important resources. These subjects should have been included in detail in school curriculum. Even though these developments are crucial for Turkey, they are still not included in political geography course taught in social studies education programs. In today's changing world order, it is vital to teach similar subjects to social studies teacher candidates because in a country like Turkey that has geopolitical importance, people should be informed about these subjects. This is possible with teaching the new developments to individuals in today's changing world conditions of this. This can only be achieved by regularly updating the political geography content.

Another problem is that the courses in social studies programs are still mostly taught with traditional methods like lectures and forces memorization. With the transformation of society from an agricultural one to industrial one, teachers avoided rote learning. The new societies need people who can think, search, criticize and discuss, not people who know more. The societies who adapt new methods in teachings were able to come to today's point in science and technology in the last 100 years. However, the countries that are still agricultural and that could not adapt modern education in their schools unfortunately fell under the influence of scientifically and technologically developed countries. In our country 
there is a more complicated situation in terms of education system (Esme, 2002; Sekin, 2008). In the teaching of political geography education, these traditional methods lost its validity in today's world. These traditional methods also bore the teacher candidates and put candidates off. Thus, student learning becomes difficult. For this reason, more modern teaching methods and techniques should be used in today's conditions.

Today, media is an integral part of the learning process. Therefore, it can be said using media in education can help to achieve academic objectives (Aiex, 1988, Kaya \& Cengelci, 2011). In this context, teachers can use documentaries and other visual resources to teach certain subjects. So, documentaries about political events, situations and conflicts can be shown in classrooms. Furthermore, in classrooms where modern teaching techniques are employed, computers, LCD projectors and internet are used as basic technologies. In the teaching of geography which examines the world we live on with all its aspects, compared to other disciplines technology is needed more. For teachers, the use of these technologies has no alternative for development of course materials, activities and methods. For students, the use of these technologies is a great tool to better understand the world they live in through geography (Demirci, Tas \& Ozel, 2007, Kaya \& Aydin, 2011). Through international news channels can follow the current political developments and the teacher candidates can be asked to interpret these developments. By arousing students' interest, they will pay more attention to class. In addition, teacher candidates can be assigned a country where conflicts happen and they can be asked to provide their opinions. So, discussion method can be used. Thus, teacher candidates can develop new ideas and can look at a certain event from different perspectives.

\section{Result and Suggestions}

Political geography is a science that is critical for a country's future. In a developing and globalizing world, the teaching political geography is essential for countries. Especially for a country like Turkey that has an important geopolitical location, the teaching of political geography should be given the utmost attention to train citizens who know world geography and Turkey's geography. The content of the political geography courses taught in social studies education programs in Turkish education faculties are determined by the interuniversity supreme board and taught accordingly. Most of the subjects are far from being updated and they should be updated to catch the political developments happening in the world.

Another problem of our country is that we still insist on teaching political geography with traditional teaching methods. Teaching techniques appropriate to the new developments and active learning methods should be used as solutions to this problem. To attract the attention of social studies teacher candidates, visual media, internet and interactive applications can be used and documentaries can be shown. Furthermore, by creating an environment for discussion in the classroom, teacher candidates can exchange ideas and they can be more open to new opinions.

Training social studies teacher candidates who are equipped with political geography subjects and who are aware of the importance of the course is essential to create brighter generations for Turkey's future. The geopolitical location of our country and the bad intentions of foreign countries necessitate us to be educated in political geography subjects. Young generation who keep pace with the developments and innovations in the world are the guarantee of our future. The educated and aware generations are the ones who will take us forward.

\section{Reference}

Aiex, N. K. (1988). Using film, video, and TV in the classroom. ERIC (ED300848)

Akengin, H. (2010). Siyasi cografya (insan ve mekan yonetimi), Pegem Yayinevi, Ankara, 2.

Akinoglu, O. (2006). Cografya egitimi ve toplum, Marmara Cografya Dergisi, 13, 25-48.

Alexander, L. (1963). World political patterns, Rand McNally, Chicago.

Aribas, K. (2007). Kuresel cagda siyasi cografya, Cizgi Yayinevi, Konya, 4-6.

Davidson, F. M. Leib, J. I. Shelley, M. \& Webster, G. R. (1998). Teaching political geography, National Council for Geographic Education, Indiana, Pennsylvania, 1-8.

Demirci, A., Tas, H. I., \& Ozel, A. (2007). Turkiye'de ortaogretim cografya derslerinde teknoloji kullanimi. Marmara Cografya Dergisi, (15), 37-54.

Demircioglu, I. H. (2005). Tarih ogretiminde ogrenci merkezli yaklasimlar, Ankara: Ani Yayincilik.

Deniz, T. (2012). Mekansal paylasim acisindan Buyuk Ortadogu Projesi ve Turkiye, Marmara Cografya Dergisi, Sayi: $26,147-171$.

Deniz, T. (2013). Arap Bahari ve Turkiye: Siyasi cografya acisindan bir degerlendirme, Dogu Cografya Dergisi, 18(29), $65-78$

Doganay, A. (2004). Sosyal bilgiler ogretimi, Cemil Ozturk-Dursun Dilek (Ed.), Hayat Bilgisi ve Sosyal Bilgiler 
Ogretimi, Dorduncu Baski, Ankara: Pegem Yayincilik, 16-44.

Esme, I. (2002). Ezberci egitim depremden beter, Cumhuriyet, 5 Temmuz 2002 , 2. http://www.cumhuriyetarsivi.com/reader/reader2.xhtml?newsId=3206879\&pageNo=2\&home $=\% 2 \mathrm{Fkatalog}$ $\% 2 \mathrm{~F} 192 \% 2 \mathrm{Fsayfa} \% 2 \mathrm{~F} 2002 \% 2 \mathrm{~F} 7 \% 2 \mathrm{~F} 5 \% 2 \mathrm{~F} 2 . x h t m l$

Geography for life: National geography standards (1994). Washington, D.C.: National Geographic Research and Exploration for the American Geographical Society, Association of American Geographers, National Council for Geographic Education, and the National Geographic Society.

Goblet, Y. (1955). Political geography and the world map, New York: Praeger.

Goney, S. (1979). Siyasi cografya, İstanbul Universitesi Yayin No: 2539, Cografya Enstitu Yayin No: 108, Cilt II, İstanbul, s.3.

Gunel, K. (2004). Cografya'nin siyasal gucu, 4. Baski, Cantay Kitabevi, İstanbul, 201-202.

Ilhan, S. (1989). Jeopolitik duyarlilik, Ataturk Kultur ve Dil Tarih Yuksek Kurumu Turk Tarih Kurumu Yayinları, VII. Dizi, 113, Ankara, 56-60.

Ilhan, S. (2000).Avrupa birligine neden hayir: Jeopolitik yaklasim, İstanbul, Otuken, 51, 52.

Jones, M. Jones, R. \& Woods, M. (2004). An introduction to political geography; Space, place and politics, Routledge, New York, 2.

Kaya, E. \& Cengelci, T. (2011). Ogretmen adaylarinin sosyal bilgiler egitiminde filmlerden yararlanmasina iliskin gorusleri, Sosyal Bilgiler Egitimi Arastirmalarin Dergisi, 2(1), 116-135.

Kaya, H., \& Aydin, F. (2011). Sosyal bilgiler dersindeki cografya konularinin ogretiminde akilli tahta uygulamalarina iliskin ogrenci gorusleri, Zeitschrift fur die Welt der Turken, 3(1), 179-189.

Ozey, R. (2013). Dunya ve Turkiye olceginde siyasi cografya, Aktif Yayinevi, 9. Baski, Erzurum, 1, 6, 8.

Ramsay, W. M. (1963). Anadolu'nun tarihi cografyasi, Ceviren: Mihri Pektas, Milli Egitim Basim Evi, İstanbul, 23.

Sekin, S. (2008). Turkiye'de ezberci ogretim ve nedenleri, Marmara Cografya Dergisi, 18, 11-221.

Sen, Y. (2013). Suriye’de Arap Bahari, Yasama Dergisi, sayi 23, 56.

Yavan, N., \& Acar, S. (2012). Turkiye'de cografyanin yansimaları, Cografi Bilimler Dergisi CBD 10 (1), 1-8.

Yesilbursa, C. C. (2008). Sosyal bilgiler ogretiminde tarihî yerlerin kullanimi, TUBAR-XXIII- Bahar, $209-222$.

http://www.nigde.edu.tr/egitimfakultesi/sosyalbilgilerogretmenligi/kisa-ders-icerik

http://www.pcr.uu.se/digitalAssets/66/66314_1map14.png

http://www.tasam.org/Files/Icerik/File/turkiye_kopru_mu_kanat_mi_merkez_mi_b4156f55-1433-4a8b-b420-0ec349a42 fef.pdf

https://www.academia.edu/19891596/Suriye_Muhalefetinin_Analizi

\section{$(\mathrm{oc}) \mathrm{BY}$}

This work is licensed under a Creative Commons Attribution 3.0 License. 